\title{
SENSITIVITY AND INSENSITIVITY OF VARIOUS TRAITS TO MUTAGEN TREATMENT IN RICE (Oryza sativa L.)
}

\author{
M. Akilan ${ }^{1}$, C. Vanniarajan ${ }^{1}$, E. Subramanian ${ }^{2}$, K. Anandhi ${ }^{3}$, G. Anand ${ }^{1, *}$ \\ ${ }^{1}$ Department of Plant Breeding and Genetics, Agricultural College and Research Institute, Tamil Nadu Agricultural University, Madurai, India. \\ ${ }^{2}$ Department of Agronomy, Agricultural College and Research Institute, Tamil Nadu Agricultural University, Madurai, India. \\ ${ }^{3}$ Krishi Vigyan Kendra, Agricultural College and Research Institute, Madurai, India.
}

Received - March 25, 2020; Revision - July 14, 2020; Accepted - July 30, 2020

Available Online - August 25, 2020

DOI: http://dx.doi.org/10.18006/2020.8(4).381.389

\section{KEYWORDS \\ Oryza sativa \\ Mutation breeding \\ Sensitivity \\ Lethality \\ Injury \\ Mutagen}

\begin{abstract}
Rice is one of the most important food crops around the world, which can be grown under wide range of environmental conditions. Mutation breeding could be particularly useful to alter one or two traits in an elite cultivar. Hence, the present study was conducted to study the sensitivity of different traits to a mutagen in a popular rice variety BPT 2231. The traits producing lethality and injury viz., germination per cent, survival per cent, shoot length, root length and seedling height exhibited dose dependent negative and linear relationship in all the mutagenic treatment. Other biometrical traits viz., Days to 50 per cent flowering, plant height, number of tillers per plant, number of productive tillers per plant, flag leaf length, flag leaf width, panicle length, panicle weight, grains per panicle, 100 grain weight and single plant yield did not show such kind of relationship with the dose of mutagen indicating they are insensitive to all the mutagen treatment. Sensitivity of the traits to a mutagen is a crucial prerequisite for assessing growth reduction values (GR50 or GR30) to find the optimum dose of a mutagen. Hence, understanding the nature of sensitivity of a trait finds its place in an effective mutation breeding programme.
\end{abstract}

* Corresponding author

E-mail: anand.g@tnau.ac.in (G. Anand)

Peer review under responsibility of Journal of Experimental Biology and Agricultural Sciences.

Production and Hosting by Horizon Publisher India [HPI] (http://www.horizonpublisherindia.in/).

All rights reserved.
All the articles published by Journal of Experimental Biology and Agricultural Sciences are licensed under a Creative Commons Attribution-NonCommercial 4.0 International License Based on a work at www.jebas.org.

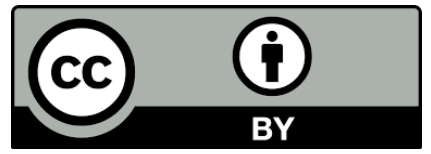




\section{Introduction}

Plant breeding plays an important role in crop improvement in rice. Rice, being one the most important cereal crop, which almost feeds half of the world's population (Tyagi et al., 2004) was a major concern for crop improvement in the later part of $19^{\text {th }}$ century. Coupling crop management practices with crop varieties specific to prevailing agro-climatic conditions played a crucial role in yield maximisation. Such varieties were developed by utilising natural genetic variation through conventional breeding techniques.

Mutation breeding has been recognised as an important tool for altering the specific undesirable trait present in any elite cultivars. Mutation breeding have been used for rice improvement for various trait like plant height (Chand et al., 2005), early maturity (Haris et al., 2013) and resistance to biotic and abiotic stresses (Abdelnour-Esquivel et al., 2020; Majeed et al., 2020) etc.

The most widely used ionising radiations, gamma rays, are high energy radiations and they are sparsely ionising. They are composed of photons and can penetrate deep into the biological systems. Out of 3330 mutants registered in mutant variety database, 1671 varieties were released using gamma rays (IAEA, 2020). This shows that gamma rays mutations are more economical and can produce mutation with high frequency.

On the other hand, chemical mutagens mainly induce point mutations, unlike ionising radiations which normally produce chromosomal rearrangements and deletions (Talebi et al., 2012b). Ethyl Methane Sulfonate (EMS) is the most commonly used chemical mutagen due to its potency as a strong mutagen and the relative ease of handling compared to other mutagens.

The evaluation of genetic variability that was created in various quantitative traits as a result of these mutagens is a preliminary step and an important objective in a mutation breeding programme. Hence, understanding how every trait respond to mutagen treatment will give a clear picture about the nature of variability created in that particular trait.

A handful of studies have already been done for the exploitation of mutation breeding leading to improvement of various traits in cereals, especially rice (Aravind et al., 2019; Yasmine et al., 2019; Yunita et al., 2020). Masruroh et al. (2016) subjected two varieties for gamma irradiation and obtained mutants with improved number of grains per panicle, 1000 grain weight and protein content. Various other agronomically important traits in rice have been improved by different mutagen treatment viz., semi dwarf stature, early maturity, profuse tillering, etc. (Chand et al., 2005). Improvement of other cereals like wheat (Nazarenko et al., 2019), barley (Akgün et al., 2019), maize (Kiruki et al., 2006), etc. have also been done using mutation breeding programme.

In the present study, rice variety BPT 2231 (Akshaya) is used to study the effect of gamma rays, EMS and its combination on various quantitatively measured traits to analyse the sensitivity/insensitivity of the particular trait to these mutagens. The inference about the sensitivity of a trait could be an useful parameter for optimising growth reduction values of the mutagen.

\section{Materials and methods}

\subsection{Plant Genetic Material}

Akshaya (BPT 2231) the long duration, fertilizer responsive and high yielding rice variety released from Rice Research Unit, Bapatla was chosen for mutagenesis. The objective of the mutation breeding programme is to reduce the duration of the crop so that it can be used in varied cropping systems. The genetically pure seeds obtained from authenticated source at a moisture content of 12 per cent were used in the present investigation.

\subsection{Mutagen Treatment}

\subsubsection{Gamma rays}

The genetically pure and well-filled seeds of the variety Akshaya were counted and subjected to mutagen treatment. The seeds were properly packed in butter paper covers prior to mutagen treatment. The Cobalt 60 gamma radiation was given to the seeds in a gamma chamber at Indira Gandhi Centre for Atomic Research, Kalpakkam. The duration of exposure were fixed in such a way that the seeds were treated with five different doses from 100 Gy to 500 Gy with 100 Gy interval. A set of untreated seeds were retained for control. On the next day, the gamma rays exposed seeds were sown in a raised nursery bed for germination. The experiment was repeated for another lot seeds to facilitate combination treatment with EMS.

\subsubsection{EMS treatment}

Similar well-filled healthy seeds were counted and used for chemical mutagenesis with EMS. The seeds were pre-soaked for eight hours in double distilled water. The seeds were then treated with three different concentrations viz., 10, 20 and $30 \mathrm{mM}$ of EMS. Intermittent shaking was done for every 30 minutes during the total treatment period of six hours. After the stipulated time, the seeds were exposed to running tap water to remove residual toxicity of EMS. Sowing of the treated seeds was done immediately after the treatment in a raised bed nursery for germination. A set of untreated seeds were retained for control.

\subsubsection{Combination treatment}

The second lot seeds that were treated with gamma rays were treated with $30 \mathrm{mM}$ EMS. The different gamma rays irradiation viz., $100 \mathrm{~Gy}, 200 \mathrm{~Gy}, 300 \mathrm{~Gy}, 400 \mathrm{~Gy}$, and $500 \mathrm{~Gy}$ gamma irradiated seeds were again treated with $30 \mathrm{mM}$ EMS for combination treatment. The methodology adopted for treatment was similar to the above experiment. A set of untreated seeds were retained for control. 


\subsection{Experimental plot and design}

The seedlings after 27 days were transplanted to the experimental plot at Agricultural College and Research Institute, Madurai during kharif, 2018. The experiment was laid out in RBD design with two replications adopting a spacing of $20 \mathrm{~cm} \times 15 \mathrm{~cm}$. Recommended package of practices were followed for maintaining the crop in a healthy state.

\subsection{In vitro and field observations recorded}

The traits viz., germination per cent, survival per cent, shoot length, root length and seedling height were recorded in the vegetative stage of the crop, whereas other traits viz., days to 50 per cent flowering, plant height, number of tillers per plant, number of productive tillers per plant, flag leaf length, flag leaf width, panicle length, panicle weight, grains per panicle, 100 grain weight and single plant yield were recorded in the crop maturity stage. The stage in which these observations were made is particularly important to interpret the results.

\subsection{Statistical analysis}

The observations recorded in appropriate stages of the crop were subjected to first order statistical analysis in statistical analysis system (S.A.S)

\section{Results and discussion}

\subsection{Effect of mutagens on lethality}

The effect of mutagen on the traits producing lethality viz., germination per cent and survival per cent are presented in Table 1. These traits exhibited dose dependent negative and linear relationship with the dose of the mutagen used for treatment. The increase in the dose of the mutagen resulted in decrease in the

Table 1 Effect of mutagenic treatment on lethality

\begin{tabular}{|c|c|c|c|c|c|c|}
\hline Treatment & $\%$ Germination & $\begin{array}{l}\% \text { over } \\
\text { control }\end{array}$ & $\begin{array}{c}\% \text { reduction over } \\
\text { control }\end{array}$ & $\%$ survival & $\begin{array}{l}\% \text { over } \\
\text { control }\end{array}$ & $\begin{array}{l}\% \text { reduction over } \\
\text { control }\end{array}$ \\
\hline \multicolumn{7}{|c|}{ Gamma rays } \\
\hline Control & 70.10 & 100.00 & 0.00 & 62.30 & 100.00 & 0.00 \\
\hline $100 \mathrm{~Gy}$ & 58.00 & 82.74 & 17.26 & 44.50 & 71.43 & 28.57 \\
\hline $200 \mathrm{~Gy}$ & 40.50 & 57.77 & 42.23 & 24.00 & 38.52 & 61.48 \\
\hline 300 Gy & 18.00 & 25.68 & 74.32 & 6.00 & 9.63 & 90.37 \\
\hline $400 \mathrm{~Gy}$ & 7.50 & 10.70 & 89.30 & 0.00 & 0.00 & 100.00 \\
\hline $500 \mathrm{~Gy}$ & 3.40 & 4.85 & 95.15 & 0.00 & 0.00 & 100.00 \\
\hline Mean & 25.48 & - & 63.65 & 14.90 & - & 76.08 \\
\hline SE & 11.30 & - & - & 10.57 & - & - \\
\hline \multicolumn{7}{|c|}{ EMS } \\
\hline Control & 70.10 & 100.00 & 0.00 & 62.30 & 100.00 & 0.00 \\
\hline $10 \mathrm{mM}$ & 65.69 & 93.71 & 6.29 & 55.08 & 88.41 & 11.59 \\
\hline $20 \mathrm{mM}$ & 57.85 & 82.52 & 17.48 & 46.31 & 74.33 & 25.67 \\
\hline $30 \mathrm{mM}$ & 49.85 & 71.11 & 28.89 & 37.85 & 60.75 & 39.25 \\
\hline Mean & 57.79 & - & 17.55 & 46.41 & - & 25.51 \\
\hline SE & 4.46 & - & - & 5.31 & - & - \\
\hline \multicolumn{7}{|c|}{ Gamma rays + EMS } \\
\hline Control & 70.10 & 100.00 & 0.00 & 62.30 & 100.00 & 0.00 \\
\hline $100 \mathrm{~Gy}+30 \mathrm{mM}$ & 52.89 & 75.45 & 24.55 & 35.11 & 56.36 & 43.64 \\
\hline $200 \mathrm{~Gy}+30 \mathrm{mM}$ & 34.67 & 49.45 & 50.55 & 13.78 & 22.12 & 77.88 \\
\hline $300 \mathrm{~Gy}+30 \mathrm{mM}$ & 12.89 & 18.39 & 81.61 & 2.22 & 3.57 & 96.43 \\
\hline $400 \mathrm{~Gy}+30 \mathrm{mM}$ & 5.33 & 7.61 & 92.39 & 0.00 & 0.00 & 100.00 \\
\hline $500 \mathrm{~Gy}+30 \mathrm{mM}$ & 3.11 & 4.44 & 95.56 & 0.00 & 0.00 & 100.00 \\
\hline Mean & 21.78 & - & 68.93 & 10.22 & - & 83.59 \\
\hline SE & 11.22 & - & - & 10.27 & - & - \\
\hline
\end{tabular}

Journal of Experimental Biology and Agricultural Sciences http://www.jebas.org 
values of these traits. Jiya et al. (2018) reported that disturbances caused by the mutagen at cellular and physiological levels interferes with the biological processes of the tissues and produces lethality and sterility.

The germination per cent of gamma rays treated seeds exhibited reduction, ranging from 17.26 per cent (100 Gy) to 95.15 per cent (500 Gy), while it was 6.29 per cent $(10 \mathrm{mM})$ to 28.89 per cent (30 $\mathrm{mM}$ ) in EMS treated plants. The reduction combination treatment exhibited prominent reduction in the trait and it ranged from 24.55 per cent $(100 \mathrm{~Gy}+30 \mathrm{mM})$ to 95.56 per cent $(500 \mathrm{~Gy}+30 \mathrm{mM})$. Similar findings stating dose dependent decrease in germination per cent was reported by Talebi et al. (2012b), Tyagi et al. (2004), Vasline (2013) and Raina \& Khan (2020). Results of Talebi et al. (2012a) are contradictory to the findings of current study. These researchers have reported stimulatory effect of mutagen and they justified that this could be due to the activation of RNA or protein synthesis and this activation may occur at the early stage of treatment (Abdel-Hady et al., 2008).

The survival per cent of the seedlings also exhibited reduction ranging from 28.57 per cent (100 Gy) to 100 per cent (400 Gy and $500 \mathrm{~Gy})$ in gamma rays treatment and while in case of EMS treatment, it ranged from 11.59 per cent $(10 \mathrm{mM})$ to 39.25 per cent $(30 \mathrm{mM})$. Combination treatment produced maximum reduction in survival per cent and it ranged from 43.64 per cent $(100 \mathrm{~Gy}+30$ $\mathrm{mM})$ to 100 per cent $(400 \mathrm{~Gy}+30 \mathrm{mM}$ and $500 \mathrm{~Gy}+30 \mathrm{mM})$. Wattoo et al. (2012) used basmati rice variety and reported similar dose dependent negative relationship of the survival per cent with dose of the mutagen. The reduction in survival may be due to inability of the mutagen treated cells to repair the damage done to them by mutagens. It could be used as an important parameter for assessing toxicity of a mutagen. A similar study indicating increased lethality at higher doses of mutagenic treatment was reported by Khah \& Shaik (2020).

\subsection{Effect of mutagen on injury}

The effect of mutagen on traits producing injury viz., shoot length, root length and seedling height are presented in Table 2. The effects of mutagens on these traits were also similar to the above mentioned characters, exhibiting dose dependent negative and linear relationship.

Reduction was observed in length of the shoots in mutagen treated seedlings and it ranged from 11.14 per cent ( $100 \mathrm{~Gy}$ ) to 89.30 per cent $(500 \mathrm{~Gy})$ in gamma rays treated plants, while it was 2.05 per cent $(10 \mathrm{mM})$ to 17.42 per cent $(30 \mathrm{mM})$ in EMS treated plants. Combination of these two mutagens exhibited maximum reduction in shoot length which ranged from 58.75 per cent $(100 \mathrm{~Gy}+30 \mathrm{mM})$ to 94.45 per cent $(500 \mathrm{~Gy}+30 \mathrm{mM})$. The findings were similar to the results obtained by Chakrabarti (1975) and Sikder et al. (2013)
The root length of mutagen treated seedlings exhibited reduction which ranged from 10.56 per cent (100 Gy) to 84.78 per cent $(500$ Gy) in gamma rays treated plants and 7.37 per cent $(10 \mathrm{mM})$ to 8.8 per cent $(30 \mathrm{mM})$ in EMS treated plants. The combination treatment exhibited reduction in survival per cent ranging from 27.4 per cent $(100 \mathrm{~Gy}+30 \mathrm{mM})$ to 91.88 per cent $(500 \mathrm{~Gy}+30$ $\mathrm{mM})$. The results were similar to the findings of Minn et al. (2008), Ambavane et al. (2015) and Awais et al., (2019).

The reduction in shoot and root length of the seedlings may be because of reduction in mitotic activity in the meristematic tissues due to the effect of mutagen (Shakoor et al., 1978). Reduction in rapid division in meristematic tissues results in reduced length of shoots and roots. Khalil et al. (1986) suggested that gamma rays reduce moisture content in seeds and that may be the reason for reduced growth in seedlings.

After 20 days, the survival of seedlings were observed only up to $300 \mathrm{~Gy}$ and its combination treatments. These seedlings were subjected for further studies and used for recording biometrical observations.

Seedling height also exhibited similar results and shows reduction which ranged from 11.55 per cent (100 Gy) to 51.27 per cent (300 Gy) in gamma rays treatment and from 3.21 per cent $(10 \mathrm{mM})$ to 18.46 per cent $(30 \mathrm{mM})$ in EMS treatment. Combination treatment exhibited similar maximum reduction like other traits, which ranged from 45.17 per cent $(100 \mathrm{~Gy}+30 \mathrm{mM})$ to 52.57 per cent $(300 \mathrm{~Gy}+30 \mathrm{mM})$. Concomitant findings were reported by Sasikala \& Kalaiyarasi (2010) and Sikder et al. (2013). Singh (1974) and Ussuf \& Nair (1974) reported that mutagenic treatment causes the reduction in seedling growth because of the destruction of auxin and changes in the levels of ascorbic acid and several physiological and biochemical changes. However, the level of sensitivity of the experimental material vary with its genotype (Pérez-Jiménez et al., 2020).

\subsection{Effect of mutagen on other biometrical traits}

The other biometrical traits viz., Days to 50 per cent flowering, plant height, number of tillers per plant, number of productive tillers per plant, flag leaf length, flag leaf width, panicle length, panicle weight, grains per panicle, 100 grain weight and single plant yield were recorded and presented in Table 3. These traits showed both increase as well as decrease in their values among the mutagen treated plants in $\mathrm{M}_{1}$ generation.

The number of days to 50 per cent flowering in gamma rays and EMS treatment showed reduction in number of days to 50 per cent flowering over the control. Increase in number of days to 50 per cent flowering over the control was observed in $200 \mathrm{~Gy}+30 \mathrm{mM}$ while other doses of combination treatment showed reduction in 
Table 2 Effect of mutagenic treatment on injury

\begin{tabular}{|c|c|c|c|c|c|c|c|c|c|}
\hline Treatment & $\begin{array}{l}\text { Shoot } \\
\text { Length }\end{array}$ & $\begin{array}{l}\% \text { over } \\
\text { control }\end{array}$ & $\begin{array}{l}\% \text { reduction } \\
\text { over control }\end{array}$ & $\begin{array}{l}\text { Root } \\
\text { length }\end{array}$ & $\begin{array}{l}\% \text { over } \\
\text { control }\end{array}$ & $\begin{array}{l}\% \text { reduction } \\
\text { over control }\end{array}$ & Height & $\begin{array}{l}\% \text { over } \\
\text { control }\end{array}$ & $\begin{array}{l}\% \text { reduction } \\
\text { over control }\end{array}$ \\
\hline \multicolumn{10}{|c|}{ Gamma rays } \\
\hline Control & 8.41 & 100.00 & 0.00 & 10.51 & 100.00 & 0.00 & 11.84 & 100.00 & 0.00 \\
\hline $100 \mathrm{~Gy}$ & 7.47 & 88.86 & 11.14 & 9.40 & 89.44 & 10.56 & 10.47 & 88.45 & 11.55 \\
\hline $200 \mathrm{~Gy}$ & 3.74 & 44.47 & 55.53 & 6.38 & 60.70 & 39.30 & 6.51 & 54.98 & 45.02 \\
\hline $300 \mathrm{~Gy}$ & 3.57 & 42.45 & 57.55 & 4.86 & 46.24 & 53.76 & 5.77 & 48.73 & 51.27 \\
\hline $400 \mathrm{~Gy}$ & 1.60 & 19.02 & 80.98 & 3.40 & 32.35 & 67.65 & $\mathrm{NA}^{*}$ & $\mathrm{NA}^{*}$ & $\mathrm{NA}^{*}$ \\
\hline $500 \mathrm{~Gy}$ & 0.90 & 10.70 & 89.30 & 1.60 & 15.22 & 84.78 & $\mathrm{NA}^{*}$ & $\mathrm{NA}^{*}$ & $\mathrm{NA}^{*}$ \\
\hline Mean & 3.46 & - & 58.90 & 5.13 & - & 51.21 & 7.58 & - & 35.94 \\
\hline SE & 1.25 & - & - & 1.41 & - & - & 1.55 & - & - \\
\hline \multicolumn{10}{|c|}{ EMS } \\
\hline Control & 9.76 & 100.00 & 0.00 & 12.62 & 100.00 & 0.00 & 12.46 & 100.00 & 0.00 \\
\hline $10 \mathrm{mM}$ & 9.56 & 97.95 & 2.05 & 11.69 & 92.63 & 7.37 & 12.06 & 96.79 & 3.21 \\
\hline $20 \mathrm{mM}$ & 9.03 & 92.52 & 7.48 & 11.55 & 91.52 & 8.48 & 11.33 & 90.93 & 9.07 \\
\hline $30 \mathrm{mM}$ & 8.06 & 82.58 & 17.42 & 11.51 & 91.20 & 8.80 & 10.16 & 81.54 & 18.46 \\
\hline Mean & 8.88 & - & 8.98 & 11.58 & - & 8.21 & 11.18 & - & 10.25 \\
\hline SE & 0.38 & - & - & 0.26 & - & - & 0.50 & - & - \\
\hline \multicolumn{10}{|c|}{ Gamma rays + EMS } \\
\hline Control & 11.54 & 100.00 & 0.00 & 11.02 & 100.00 & 0.00 & 13.24 & 100.00 & 0.00 \\
\hline $100 \mathrm{~Gy}+30 \mathrm{mM}$ & 4.76 & 41.25 & 58.75 & 8.00 & 72.60 & 27.40 & 7.26 & 54.83 & 45.17 \\
\hline $200 \mathrm{~Gy}+30 \mathrm{mM}$ & 4.62 & 40.03 & 59.97 & 6.12 & 55.54 & 44.46 & 6.92 & 52.27 & 47.73 \\
\hline $300 \mathrm{~Gy}+30 \mathrm{mM}$ & 4.56 & 39.51 & 60.49 & 4.38 & 39.75 & 60.25 & 6.28 & 47.43 & 52.57 \\
\hline $400 \mathrm{~Gy}+30 \mathrm{mM}$ & 0.77 & 6.67 & 93.33 & 3.36 & 30.49 & 69.51 & $\mathrm{NA}^{*}$ & $\mathrm{NA}^{*}$ & $\mathrm{NA}^{*}$ \\
\hline $500 \mathrm{~Gy}+30 \mathrm{mM}$ & 0.64 & 5.55 & 94.45 & 0.65 & 8.13 & 91.88 & $\mathrm{NA}^{*}$ & $\mathrm{NA}^{*}$ & $\mathrm{NA}^{*}$ \\
\hline Mean & 3.07 & - & 73.40 & 4.50 & - & 58.70 & 6.82 & - & 48.49 \\
\hline SE & 1.62 & - & - & 1.49 & - & - & 1.62 & - & - \\
\hline
\end{tabular}

* Survival per cent of seedlings is zero and hence, individuals are not available for observation

the trait compared to control. The effect of mutagen on this trait was found to be erratic and their relationship with this trait is not defined. The current results were in agreement with the findings of Labrada Pons et al. (2001) and El-Degwy (2013)

All the mutagenic treatments studied exhibited reduction in mean plant height compared to the control. Although, initial height of the seedlings was dose dependent, the final plant height of the seedlings did not exhibit dose dependent relationship (Ashraf et al., 2003).

The number of tillers per plant in gamma rays and EMS treatment showed reduction in number of tillers compared to control (28.30). Increase in mean number of tillers over the control was observed in $200 \mathrm{~Gy}+30 \mathrm{mM}$ treatment combination dose, while other doses exhibited reduction in mean number of tillers. Results of the current study are in agreement with Harding et al. (2012).
The mean number of productive tillers per plant was found to be reduced in gamma rays treatment as well as in EMS treatment compared to the control (19.50). In case of combination treatment, increase in number of productive tillers per plant over the control was observed in $200 \mathrm{~Gy}+30 \mathrm{mM}$ treatment while, all other doses showed reduction in the trait.

The length and breadth of flag leaves were observed in mutagen treated and control plants. Surprisingly, all the mutant plants showed increased in flag leaf length in all the doses of treatment compared to control. Increase in flag leaf breadth over the control was observed in 100 Gy while all other doses in gamma rays treatment showed no increase in breadth of flag leaf compared to control $(1.43 \mathrm{~cm})$. In case of EMS treatment, increase in breadth of flag leaf over the control was observed in $10 \mathrm{mM}$ treatment. The flag leaf breadth in $100 \mathrm{~Gy}+30 \mathrm{mM}$ combination treatment showed neither increase nor decrease in the value, but other doses exhibited reduction over the control. 


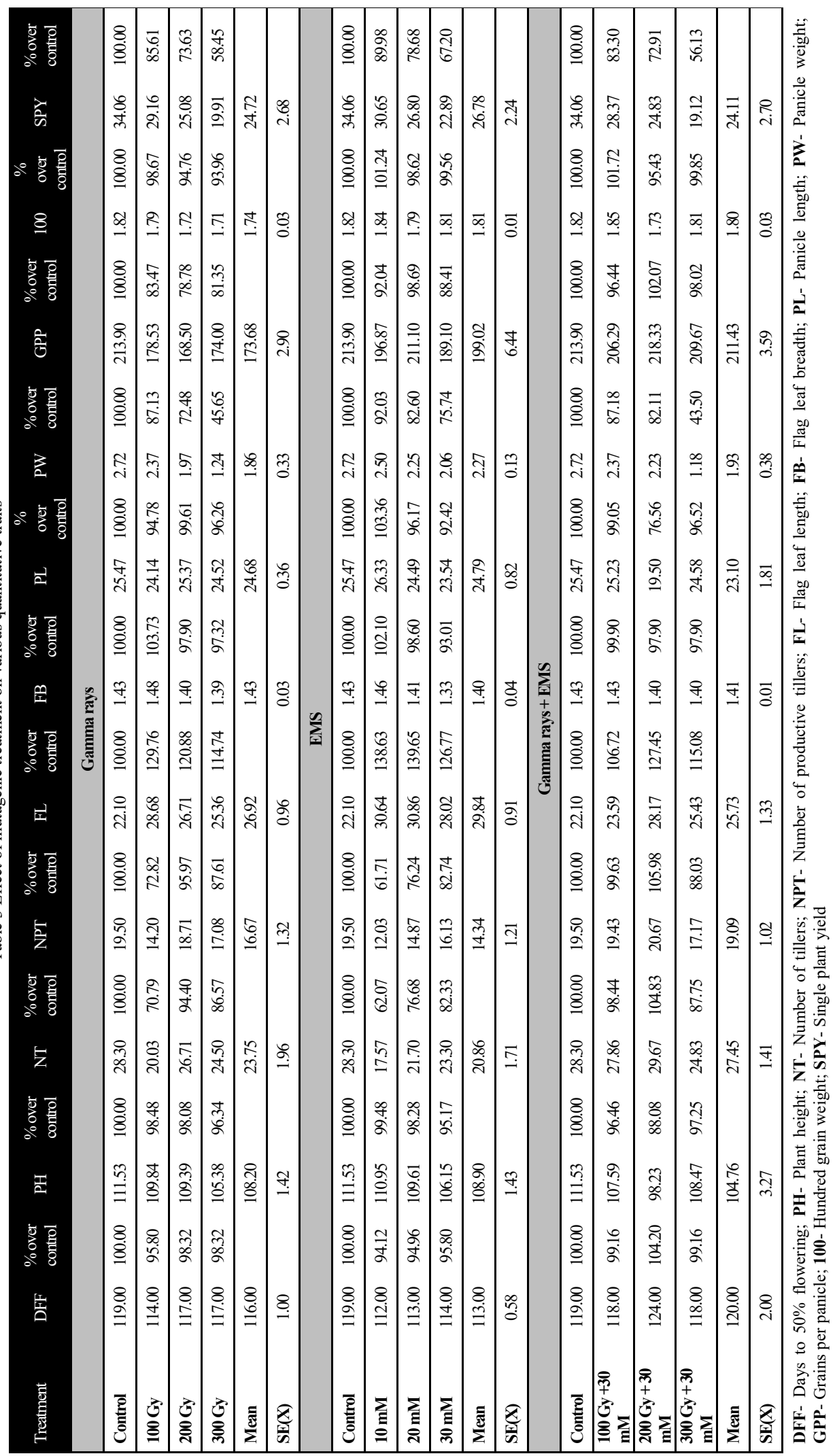

Journal of Experimental Biology and Agricultural Sciences http://www.jebas.org 

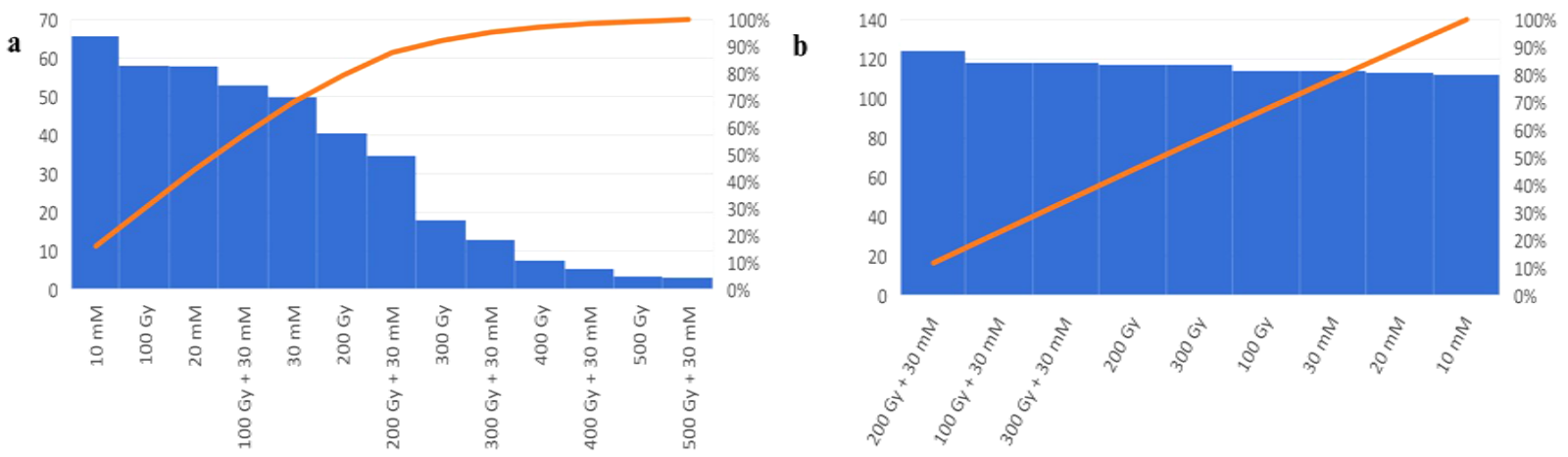

Figure 1 Vegetative stage traits Vs Reproductive stage traits; a. Pareto chart showing treatments with decreasing order of their treatment data for traits viz., germination per cent, survival per cent, shoot length, root length and seedling height; b. Pareto chart showing decreasing order of their treatment data for traits viz., Days to 50 per cent flowering, plant height, number of tillers per plant, number of productive tillers per plant, flag leaf length, flag leaf width, panicle length, panicle weight, grains per panicle, 100 grain weight and single plant yield.

The panicle length in gamma rays treatment and combination treatment exhibited reduction over control in all the doses of the treatment, while, in case of panicle length in EMS treated plants, increase in mean length of panicles over the control was observed in $10 \mathrm{mM}$ treatment and all other doses exhibited reduction in length of the panicles over the control.

The weight of a panicle in all the mutagenic treatment showed reduction in the trait compared to control. It exhibited dose dependent negative relationship with the dose of the mutagen in all the mutagenic treatments. The reduction in the weight with increasing dose of the mutagen may be attributed to production of increased sterile spikelets at higher doses. The results obtained from the current study were in agreement with the findings of Gowthami et al. (2016).

The number of grains per panicle in gamma rays treated plants as well as EMS treated plants showed reduction in number of grains per panicle over the control (213.90) in all the treatment doses. The reduction in number of grains per panicle over the control was observed in $100 \mathrm{~Gy}+30 \mathrm{mM}$ and $300 \mathrm{~Gy}+30 \mathrm{mM}$ combination treatment while increase in the number of grains per panicle over the control was observed in $200 \mathrm{~Gy}+30 \mathrm{mM}$ treatment. The results from previous findings (Imam \& Chakraborty, 2018) also suggest that there is a lack of relationship between dose of mutagen and the number of grains per panicle.

Increase in mean hundred grain weight over the control (1.82) was observed in 100 Gy treatment while other doses showed reduction in mean hundred grain weight over the control. The hundred grain weight in $10 \mathrm{mM}$ EMS treatment exhibited increase in the value, while, all other doses exhibited reduction in weight over the control. Reduction in hundred grain weight over the control was observed in $200 \mathrm{~Gy}+30 \mathrm{mM}$ treatment while all other doses were similar to the control. A similar result was obtained by Masruroh et al. (2016). They used two rice varieties and reported increase as well as decrease in the mean grain weight, when the gamma rays dose was increased from 100 Gy to $500 \mathrm{~Gy}$. They concluded that irradiation with 200 Gy gamma could be used for the improvement of grains per panicle and 1000 grain weight.

The single plant yield in all the mutagenic treatment exhibited dose dependent negative and linear relationship with the dose of the mutagen. The reduction in this trait may also be attributed to the increased number of sterile spikelets at higher doses of the treatment. The results were in agreement with the findings of El-Degwy (2013).

All these biometrical traits that were taken in the later stages of the crop do not show any dependency to the mutagen treatment. The dependency of panicle weight and single plant yield may also however be attributed to increased number of sterile spikelets. Akilan et al. (2019) have also reported such increase in the number of sterile spikelets with increasing dose of the mutagen. Insensitivity of these traits may be due to efficient repair mechanisms that plants adopt to eliminate the toxic effects of mutagen. Hence, traits that are observed in later stages of the crop do not exhibit sensitivity to any mutagen. The results of the current study were in agreement with the previous findings of Desai et al. (2018), Imam \& Chakraborty (2018) and Gowthami et al. (2016).

The sensitivity behaviour of traits recorded in vegetative stage Vs reproductive stage were compared and depicted using Figure 1. The treatment data were placed in decreasing order in these pareto chart. The treatment doses increases as their value decreases in figure 1a, whereas, treatment doses were irregular as the treatment value decreases in figure $1 \mathrm{~b}$. 


\section{Conclusion}

Different traits were observed in the mutagen treated plants to study the sensitivity of the traits to the mutagen in the popular variety BPT 2231. In this view, the observations were recorded in the $M_{1}$ generation in two different crop growth stages, early vegetative stage and maturity stage. It was concluded that, traits observed in the early vegetative stage exhibited dose dependent negative and linear relationship, while, the traits observed in maturity stage did not show such relationship in all the mutagenic treatments. This may be attributed to efficient repair mechanisms to eliminate the toxic effects of mutagen in treated plants.

The knowledge about the sensitivity and insensitivity of the traits are very crucial for assessing growth reduction values (GR50 or GR30) to find the optimum dose of mutagen. There is no point in calculating optimum dose of a mutagen using insensitive traits as a measure. Hence, traits showing sensitivity to a mutagen viz., germination per cent, survival per cent, shoot length, root length and seedling height, have to be used for fixing GR values to find the optimum dose of a mutagen.

\section{Author's contributions}

GA and MA conceived the work and designed the experiments. MA mutated the seed material and performed the experiments. CV, ES and KA provided advice on experiments. MA analysed the results. MA and GA wrote and revised the manuscript.

\section{Acknowledgment}

The authors extend our deepest gratitude to Dr. B. Venkataraman and Shri. B. Harikrishnan, Indira Gandhi Centre for Atomic Research, Kalpakkam for helping us in gamma rays irradiation of the seed material.

\section{Conflict of interest}

The authors declare that they have no conflict of interest

\section{References}

Abdel-Hady M, Okasha E, Soliman S, Talaat M (2008) Effect of gamma radiation and gibberellic acid on germination and alkaloid production in Atropa belladonna L. Australian Journal of Basic and Applied Sciences 2: 401-405.

Abdelnour-Esquivel A, Perez J, Rojas M, Vargas W, Gatica-Arias A (2020) Use of gamma radiation to induce mutations in rice (Oryza sativa L.) and the selection of lines with tolerance to salinity and drought. In Vitro Cellular \& Developmental Biology-Plant 56: 88-97.

Akgün İ, Karakoca TA, Karaman R (2019) Effect of Different Gamma Ray Doses on Some Agricultural Characteristics of Two
Row Barley (Hordeum vulgare L.). Turkish Journal of AgricultureFood Science and Technology 7: 86-92.

Akilan M, Anand G, Vanniarajan C, Subramanian E, Anandhi K (2019) Study on the impact of mutagenic treatment on pollen and spikelet fertility and its relationship in rice (Oryza sativa L.). Electronic Journal of Plant Breeding 10: 525-534.

Ambavane A, Sawardekar S, Sawantdesai S, Gokhale N (2015) Studies on mutagenic effectiveness and efficiency of gamma rays and its effect on quantitative traits in finger millet (Eleusine coracana L. Gaertn). Journal of Radiation Research and Applied Sciences 8: 120-125.

Aravind K, Banumathy S, Vanniarajan C, Arunachalam P, Ilamaran M, Kalpana K (2019) DUS characterization and genetic variability studies of rice mutants. Electronic Journal of Plant Breeding 10: 451-461.

Ashraf M, Cheema A, Rashid M, Zia-ul-Qamar (2003) Effect of gamma rays on M1 generation in basmati rice. Pakistan Journal of Botany 35: 791-795.

Awais A, Nualsri C, Soonsuwon W (2019) Induced Mutagenesis for Creating Variability in Thailand's Upland Rice (Cv. Dawk Payawm and Dawk Kha 50) using Ethyl Methane Sulphonate (EMS). Sarhad Journal of Agriculture 35: 293-301.

Chakrabarti S (1975) Effect of combined x-ray and diethyl sulphate treatments on mutation frequencies in rice (Oryza sativa L.). Radiation Botany 15: 417-421.

Chand U, Katoch P, Kumar V (2005) Variability Studies in Some Macromutations Induced by EMS and Gamma Rays in Basmati Rice T-23. Annals of Biology 21: 137.

Desai S, Ramteke A, Gaikwad N, Dhole V (2018) Effect of Gamma Rays, EMS and Sodium Azide on Quantitative Characters in Kala Jirga Non-Basmati Aromatic Rice (Oryza Sativa L.) Cultivar from Kolhapur India. Vienna (Austria): Joint FAO/IAEA Division of Nuclear Techniques in Food and Agriculture, Pp. 101.

El-Degwy (2013) Mutation induced genetic variability in rice (Oryza sativa L.). International Journal of Agriculture and Crop Sciences 5: 2789-2794.

Gowthami R, Vanniarajan C, Souframanien J, Pillai MA (2016) Effect of Gamma Rays and Electron Beam on Various Quantitative Traits of Rice (Oryza sativa L.) in M1 Generation. Advances in Life Sciences 5: 1876-1882.

Harding S, Johnson S, Taylor D, Dixon C, Turay M (2012) Effect of gamma rays on seed germination, seedling height, survival percentage and tiller production in some rice varieties cultivated in Sierra Leone. American Journal of Experimental Agriculture 2: 247-255. 
Haris A, Abdullah B, Subaedah A, Jusoff K (2013) Gamma ray radiation mutant rice on local aged dwarf. Middle-East Journal of Scientific Research 15: 1160-1164.

IAEA (2020) Mutant Variety Database V2.0.5575.27348. Vienna, Austria: Joint FAO/IAEA Division.

Imam Z, Chakraborty NR (2018) Effect of Gamma Rays on Nonbasmati Aromatic Rice in M1 Generation. International Journal of Current Microbiology and Applied Sciences 7: 4412-4418.

Jiya M, Olamide F, Yusuf DOA, Abdulhakeem A, Muhammad ML, Zulukanaini SB, David TS (2018) Effects of gamma irradiation on submergence tolerance of two selected varieties of lowland rice (Oryza sativa L.). GSC Biological and Pharmaceutical Sciences 2: 31-37.

Khah MA, Shaik N (2020) Evaluation of mutagenic efficiency and effectiveness of gamma irradiation doses in two cultivars of bread wheat (Triticum aestivum L.). Research Journal of Agriculture and Forestry Sciences 8: 29-33.

Khalil SK, Rehman S, Afridi K, Jan MT (1986) Damage induced by gamma radiation in morphological and chemical characteristics of barley. Sarhad Journal of Agriculture 2: 45-54.

Kiruki S, Onek LA, Limo M (2006) Azide-based mutagenesis suppresses Striga hermonthica seed germination and parasitism on maize varieties. African Journal of Biotechnology 5: 866-870.

Labrada Pons M, Millan Wert A, Gonzalez Cepero MC (2001) Radiosensitivity of rice variety Perla. Centro Agricola 28: 5-8.

Majeed A, Muhammad Z, Siyar S (2020). The Role of Ionizing Radiation-Induced Mutations in the Development of Rice Cultivars. In: Rakshit A, Singh HB, Singh AK, Singh US, Fraceto L (Eds.), New Frontiers in Stress Management for Durable Agriculture, Springer, Singapore: Pp. 129-144.

Masruroh F, Samanhudi S, Yunus A (2016) Improvement of rice (Oryza sativa L.) var. Ciherang and Cempo Ireng productivity using gamma irradiation. Journal of Agricultural Science and Technology B 6: 289-294.

Minn M, Khai A, Lwin K (2008). Study on the effect of gamma radiation on rice Sin Thwe Latt (IR 53936). In: GMSARN Proceedings of International Conference on Sustainable Development: Issues and Prospects for the Greater Mekong Subregion, Kunming, China, Pp. 12-14.

Nazarenko M, Beiko V, Bondarenko M (2019) Induced mutations of winter wheat caused by gamma-rays fixed on plant height and stem structure. Agriculture and Forestry 65: 75-83.

Pérez-Jiménez M, Tallón CI, Pérez-Tornero O (2020) Inducing mutations in Citrus spp.: Sensitivity of different sources of plant material to gamma radiation. Applied Radiation and Isotopes 157: 109030.
Raina A, Khan S (2020) Mutagenic effectiveness and efficiency of gamma rays and sodium azide in M2 generation of Cowpea [Vigna unguiculata (L.) Walp.]. bioRxiv. Preprint at https://doi.org/10.1101/2020.03.09.983486

Sasikala R, Kalaiyarasi R (2010) Sensitivity of rice varieties to gamma irradiation. Electronic Journal of Plant Breeding 1: 885-889.

Shakoor A, Hassan Mu, Saleem M, Sadiq M, Haq M (1978) Radiosensitivity in four spring wheat varieties. Nucleus 15: 23-26.

Sikder S, Biswas P, Hazra P, Akhtar S, Chattopadhyay A, Badigannavar A, D'Souza S (2013) Induction of mutation in tomato (Solanum lycopersicum L.) by gamma irradiation and EMS. Indian Journal of Genetics 73: 392-399.

Singh B (1974) Radiation-induced changes in catalase, lipase and ascorbic acid of safflower seeds during germination. Radiation Botany 14: 195-199.

Talebi AB, Talebi AB, Jafarpour M (2012a) Identify the Lethal Dose of EMS and Gamma Radiation Mutagenesis in Rice MR219. International Proceedings of Chemical, Biological \& Environmental Engineering 48: 22-26.

Talebi AB, Talebi AB, Shahrokhifar B (2012b) Ethyl methane sulphonate (EMS) induced mutagenesis in Malaysian rice (cv. MR219) for lethal dose determination. American Journal of Plant Sciences 3: 1661

Tyagi AK, Khurana JP, Khurana P, Raghuvanshi S, Gaur A, Kapur A, Gupta V, Kumar D, Ravi V, Vij S (2004) Structural and functional analysis of rice genome. Journal of genetics 83: 79-99.

Ussuf K, Nair P (1974) Effect of gamma irradiation on the indole acetic acid synthesizing system and its significance in sprout inhibition of potatoes. Radiation Botany 14: 251-256.

Vasline A (2013) An investigation on induced mutations in rice (Oryza sativa L.). Plant Archives 13: 555-557.

Wattoo J, Aslam K, Shah S, Shabir G, Sabar M, Naveed S, Waheed R, Muqaddasi Q, Arif M (2012) Ethyle methane sulphonate (EMS) induced mutagenic attempts to create genetic variability in Basmati rice. Journal of Plant Breeding and Crop Science 4: 101-105.

Yasmine F, Ullah MA, Ahmad F, Rahman MA, Harun AR (2019) Effects Of Chronic Gamma Irradiation On Three Rice Varieties. Jurnal Sains Nuklear Malaysia 31: 1-10.

Yunita R, Dewi IS, Lestari EG, Purnamanengsih R, Rahayu S (2020) Formation of upland rice drought-tolerant mutants by mutation induction and in vitro selection. Biodiversitas Journal of Biological Diversity 21: 1476-1482. 